\title{
Assessment of building failure within and around quarries
}

\author{
A. A. Adetoyinbo \\ Department of Physics, University of Ibadan, Nigeria. Email: dejiade39@yahoo.com
}

Copyright @ 2019 Adetoyinbo. This article remains permanently open access under the terms of the Creative Commons Attribution License 4.0, which permits unrestricted use, distribution, and reproduction in any medium, provided the original work is properly cited.

Received 7th May, 2018; Accepted 8th June 2018

\begin{abstract}
The substructures of various engineering structures that were erected on the earth are being were been supported by the soil. Hence, the nature of the soil supporting these structures becomes an important issue. Quarry blasting peak particle velocity (QBPPV) is not sufficient to ascertain the causes of foundation failure, therefore, the physical parameters governing the competency of the soil supporting engineering structures need to be determine. This work investigated the possible causes of foundation failure of buildings within the vicinity of quarries. The investigation was done by carrying out Vertical Electrical Sounding (VES) and Radial Vertical Electrical Sounding (RVES) using Campus omega terrameter. The results show that buildings found within this area have shallow foundation and their foundations founded on sandy clay which can still support foundation The values of the degree of fracturing was found not to exceed 1.53 in this region which was not the case with the previous radial vertical electrical soundings, 1.94 was calculated as the highest degree of fracturing for RVES 1 while 1.83 was calculated for RVES 2. In all the RVES, degree of fracturing ranges between 1.02 to 1.94 .
\end{abstract}

Keywords: Blasting, peak particle velocity, substructure failure.

\section{INTRODUCTION}

There have been several complaints resulting from blasting activities of quarries as far back as the 1890's mostly in terms of destruction to buildings. According to Omosanya and Ajibade (2011), one of such are those of the residents of Odo-Ona kekere living within the vicinity of Ratcon Quarry Odo-ona Kekere (Elelubo) area of Ibadan. However, apart from design error that affect foundations, another problem is that of foundation inadequacies that result from sitting them on incompetent Earth layers as stated by Adelusi et al. (2013), it poses a serious threat to the buildings. Therefore, a geophysical investigation is necessary around the quarry site in order to reveal possible sub-surface problems.

Electrical resistivity methods (ERM) were used which incorporated the vertical electrical sounding to delineate the geo-electric parameters (resistivity and thickness) of the sub-surface, and azimuth radial vertical electrical sounding to investigate if there are fractures in the bedrock which will aid the transition of extremely low frequencies (i.e. electromagnetic fields of frequency below $300 \mathrm{~Hz}$ ) being generated around quarry sites. In quarry blast, the excess explosives energy, not utilized in shattering of rocks, is transferred to the elastic zone and thus propagates the disturbance away from the explosion sites. A large seismic energy is produced by the explosive charges that was generated in the elastic zone, some of them will be transmitted in form of stress waves beyond the area of the fragmented rock. Any ground mining activity can likely generate blast-induced earthquakes. Blastinduced earthquakes are experienced frequently in many areas around the world e.g. Central Europe, South Africa, Australia, and Nigeria. The intensives seismic activity in the mine has been frequently studied in order to identify precursors to the earthquakes. There are problems that are likely to be present during and after activity. These effects on humans usually ranges from ground vibration, air-overpressure, structural response, human response among others. The motion from a large blast can be received from far away (Richard et al., 1970). This ground vibration could cause damage to near-by buildings especially if there are fractures in the bedrock that helps transmit these waves. Peak particles velocity and ground 
motion frequency are the parameters used to predict these ground vibrations. A building foundation generally refers to a structural system which is also part of a building structure usually below the ground level, that serves to transfer the loads from the buildings or structures to natural or artificial bedding that is, a foundation supports the weight or load of any construction work (Paolucci, 1997). When settlement exists around a working field, blasting can have effect on the environment. Close residents suffer most from these effects (Felice 1993, Uysal et al., 2004). In any blasting design, the maximum amount of explosives per delay must be determine to eradicate these environmental problems according to (Johnson and Durucan 1994). The seismic energy released after the explosion create a rock deformation through particle motion. The particle motion generates ground vibrations (Singh and Pal Roy, 1993). The vibration problem arise from blasting may be minimized by a number of factors such as maximum charge per delay; distance from the blast, delay period used and blast geometry, etc, (Venkatesh 2005).

\section{Geology of the study area}

Ibadan, a region in the Southwestern part of Nigeria located in the south-eastern part of Oyo state about 120 $\mathrm{km}$ east of the border with the Republic of Benin in the forest zone close to the boundary between the forest and the savanna. The city ranges in elevation from $150 \mathrm{~m}$ in the valley area to $275 \mathrm{~m}$ above sea level on the major north-south ridge which crosses the central part of the city. The city is naturally drained by four rivers. It has a tropical wet and dry climate with a lengthy wet season and relatively constant temperature throughout the course of the year. Ibadan is dominated by rock types such as granite and granitic schist of the metasedimentary series, banded by gneiss and granite gneiss, augen gneiss and migmatite complex (Okunola et al., 2009). Quartzite outcrops occur as ridges with relatively high elevation and are commonly schistose in nature. The study point is Odo ona Kekere in Oluyole Local Government area of Ibadan, serving as an abode for a quarry named Ratcon. It lies between longitude $7^{\prime} 16^{\prime} 56.5^{\prime \prime}$ to $7^{0} 17^{\prime} 26.4^{\prime \prime}$ and latitude $3^{0} 50^{\prime} 49.1^{\prime \prime}$ to $3^{0} 51^{\prime} 17.1^{\prime \prime}$. The elevation ranges from 151 to $179 \mathrm{~m}$. The geological map of the study area is shown Figure 1.

Quarrying activities carries with it problems which are major consideration in structural failure in its surrounding areas as a result of the extremely low frequency being associated with blasting, it travels several kilometers away from the blasting point provided there are fractures in the bedrock to aid its transmission. It has been established that Ratcon Quarry exceeds the $50.8 \mathrm{~mm} / \mathrm{s}$ peak particle velocity recommended by the United States Bureau of mines (Adetoyinbo et al, 2010; Hammed, 2011) which could possibly cause structural damage. However, the lithology of the area needs to be investigated using geophysical methods in order to confirm that the buildings in the vicinity of the quarry are not erected on incompetent geological materials such as clay. Also, it is necessary to investigate if there are fractures in the bedrock, the degree of fracturing, and its orientation if truly there are fractures which could serve as a media for the transmission of extremely low frequency.

The aim of the work is to establish the actual causative factor for foundation failure in buildings around the Odoona Kekere (Elelubo) area of Oyo state, southwestern Nigeria. The objectives were to determine the degree and orientation of the fracture if it truly exists and make a suitable recommendation for residents of the area.

\section{METHODOLOGY}

An omega campus terrameter with an inbuilt rechargeable 12 volts battery was employed in the survey. The instrument has power source signal sender and receiver and takes consecutive resistance readings of the subsurface which are averaged continuously. It also has inbuilt error detectors which help to check errors associated with field operations. Measurement can be read in 1, 5, 10 and 20 cycle time for accuracy and precision. It has an important resolution of 0.005 at $20 \mathrm{~mA}$. A beeper signal and a simple display code tell the operator to change parameters or to check circuits. Traverses were laid within $1500 \mathrm{~m}$ away from the quarry site for the (VES) while for (RVES) traverses were laid within $1000 \mathrm{~m}$ from the site. The VES data obtained using Schlumberger configuration with spacing ranging from 1.0 to $55 \mathrm{~m}$ were interpreted with the use of convectional curve matching technique and quantitative interpretation using WINRESIST program to determine the layer model parameters. To estimate fracture strike from the RVES data, graphical procedure using polar plots were used whereby apparent resistivity was plotted against azimuths. The investigation and the result from this work was superimposed on the earlier determined peak-particle velocity (PPV) of the Ratcon quarry. The PPV which was determined from ground vibrations, Geo-Electrical Potential and Ultra Low Frequency precursory signals associated with artificially induced earthquakes was used to determine the maximum quantity of explosives that should be detonated in order not to cause damage to buildings and structures around the sites.

\section{Theory}

The Schlumberger configuration was used for the resistivity; the apparent resistivity for the arrangement is given as:

$$
\rho_{a s}=\frac{2 \pi R}{8 a}\left(L^{2}-a^{2}\right)=\frac{\pi R}{4 a}\left(L^{2}-a^{2}\right)
$$

However, for most purposes, $L^{2}>>a^{2}$, hence 


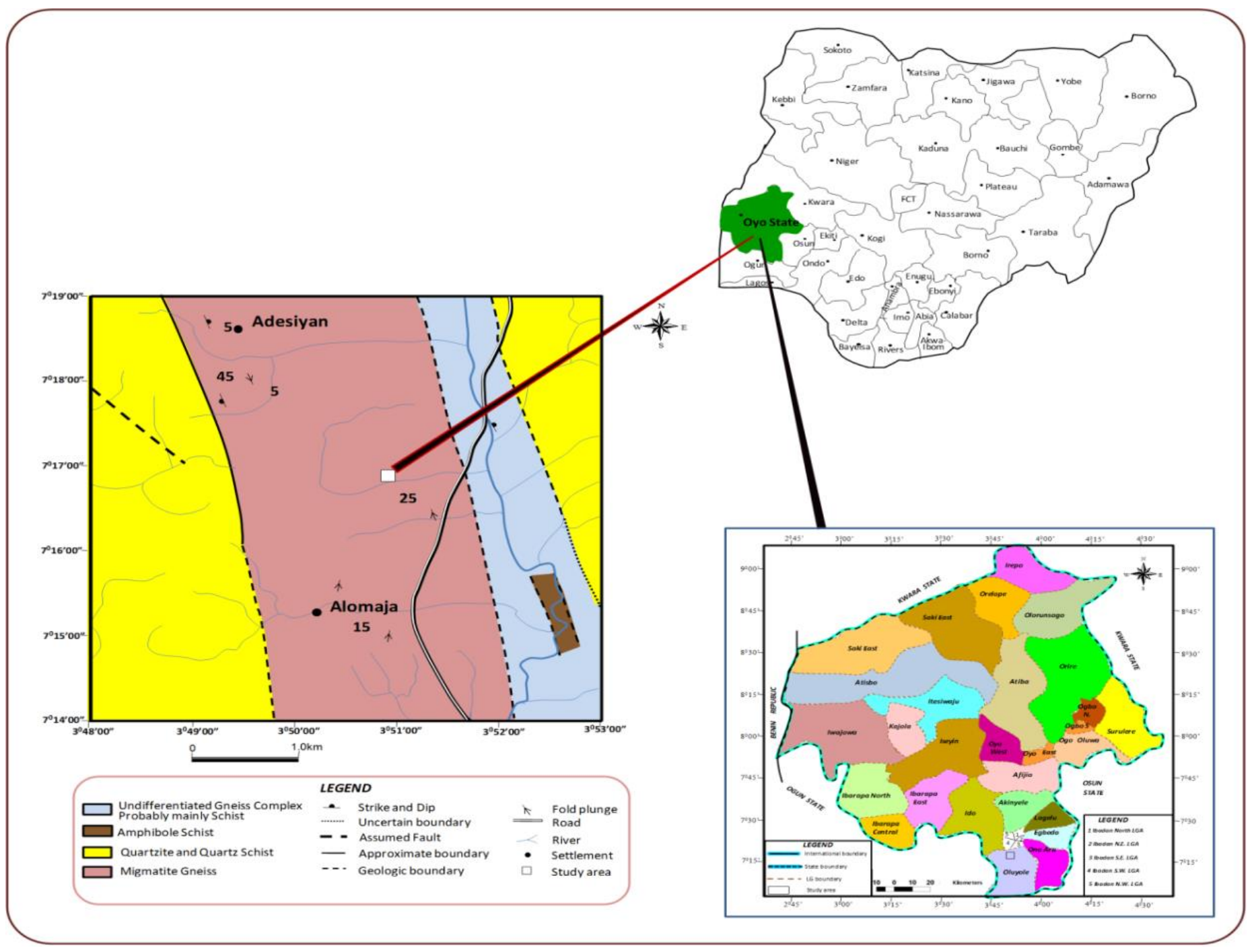

Figure 1. Geological map showing the study area.

$\rho_{a s}=\frac{\pi R L^{2}}{4 a}$

Where $L$ and a are the separation between the current and potential electrodes, $\mathrm{R}$ is the resistance and $\rho_{a s}$ is the apparent resistivity.

\section{RESULTS AND DISCUSSION}

Nine Schlumberger depth sounding points were covered within the study area. The data acquired are presented as frequency distribution charts, sounding curves and geoelectric sections. Table 1 shows the summary of the VES result in terms of the geo-electric properties of the study area. These parameters were also used in preparing geoelectric sections as well. The Table 1 shows the results obtained from the computer iteration and their inferred lithology. The calculation of the reflection coefficient for each of the VES points which gave the result shown in the last column was done using the method of Olayinka (1996) and Bhattacharya and Patra (1968).

Two to five major geologic units were delineated which includes the topsoil/lateritic soil, clayey sand/sandy clay, sandy soil, the fractured/weathered basement and the fresh basement. Topsoil/lateritic soil have a resistivity value which ranges from 52 to $591.4 \Omega \mathrm{m}$ with a thickness value between 0.5 to $1.7 \mathrm{~m}$. Clayey sand/sandy clay has a resistivity value ranging from 38 to $93.5 \Omega \mathrm{m}$ with a thickness value between 2.8 to $8.9 \mathrm{~m}$. Sandy soil has a resistivity ranging from 102.6 to $296 \Omega \mathrm{m}$ and a thickness range of 1.3 to $20.3 \mathrm{~m}$. The fractured basement however has a resistivity between 275 to $3772.4 \Omega \mathrm{m}$ and fresh basement ranging from 2646.9 to $3772.4 \Omega \mathrm{m}$. The geoelectric sections generated along W-E, W-SW, N-S and NW-SE profiles showed the uneven distribution of the degree of weathering in the area, and revealed the geo- 
Table 1. Summary of the layer model interpretation for the sounding data and the local geology in the vicinity of the VES points.

\begin{tabular}{|c|c|c|c|c|c|}
\hline Station & Layer & $\begin{array}{c}\text { Apparent Resistivity } \\
\text { Value (m) }\end{array}$ & $\operatorname{Depth}(m)$ & Probable lithology & $\begin{array}{c}\text { Reflection } \\
\text { co-efficient }\end{array}$ \\
\hline \multirow{4}{*}{ VES 1} & 1 & 57 & & Top soil & \multirow{4}{*}{0.79} \\
\hline & 2 & 93.5 & 1.0 & Clayey sand & \\
\hline & 3 & 102.6 & 7.3 & Sandy soil & \\
\hline & 4 & 854.3 & 12.7 & Weathered basement & \\
\hline \multirow{4}{*}{ VES 2} & 1 & 238.8 & & Top soil & \multirow{4}{*}{0.72} \\
\hline & 2 & 79.4 & 0.7 & Clayey Sand & \\
\hline & 3 & 293.9 & 2.8 & Sandy Soil & \\
\hline & 4 & 1784.1 & 12.3 & Weathered Basement & \\
\hline \multirow{3}{*}{ VES 3} & 1 & 444.8 & & Top soil & \multirow{3}{*}{0.89} \\
\hline & 2 & 52.4 & 0.5 & Sandy Clay & \\
\hline & 3 & 917.8 & 6.9 & Fractured Basement & \\
\hline \multirow{4}{*}{ VES 4} & 1 & 162.8 & & Top soil & \multirow{4}{*}{0.96} \\
\hline & 2 & 270.7 & 0.6 & Sandy Soil & \\
\hline & 3 & 40.6 & 1.3 & Sandy Clay & \\
\hline & 4 & 2023.6 & 4.5 & Fresh Basement & \\
\hline \multirow{4}{*}{ VES 5} & 1 & 52.1 & & Top soil & \multirow{4}{*}{0.77} \\
\hline & 2 & 109.4 & 0.7 & Sandy Soil & \\
\hline & 3 & 35.9 & 2.2 & Clayey soil & \\
\hline & 4 & 275.3 & 9.6 & Fractured Basement & \\
\hline \multirow{3}{*}{ VES 6} & 1 & 113.8 & & Top Soil & \multirow{3}{*}{0.57} \\
\hline & 2 & 136.3 & 1.0 & Sandy Soil & \\
\hline & 3 & 492.6 & 10.4 & Fractured Basement & \\
\hline \multirow{2}{*}{ VES 7} & 1 & 53.9 & & Top soil & \multirow{2}{*}{0.96} \\
\hline & 2 & 2646.9 & 1.7 & Fresh Basement & \\
\hline \multirow{4}{*}{ VES 8} & 1 & 474.0 & & Top soil & \multirow{4}{*}{0.98} \\
\hline & 2 & 679.5 & 1.5 & Lateritic layer & \\
\hline & 3 & 38.5 & 2.1 & Sandy Clay & \\
\hline & 4 & 3772.4 & 8.9 & Fresh Basement & \\
\hline \multirow{4}{*}{ VES 9} & 1 & 591.4 & & Top soil & \multirow{4}{*}{0.64} \\
\hline & 2 & 67.1 & 0.8 & Sandy Clay & \\
\hline & 3 & 310.0 & 3.6 & Sandy Soil & \\
\hline & 4 & 1432.7 & 20.3 & $\begin{array}{l}\text { Weathered/fractured } \\
\text { Basement }\end{array}$ & \\
\hline
\end{tabular}

electric layers that foundation can be laid on (Figures 2ad). The layers revealed are topsoil/lateritic soil, sandy clay/clayey sand and sandy soil which still have the strength to hold the foundation of buildings found on them.

\section{Radial vertical electrical sounding investigation}

Radial VES was carried out at points that are randomly distributed within $1 \mathrm{~km}$ away from the Quarry site in three different locations in the study area. The graph of the degree of fracturing against electrode spacing for each location while considering all the current electrodes spacing points were shown in Figures 3a-c, with this, it will be obvious to see if there are fractures at shallow depths since the $A B / 2$ values equal to $1,1.3,1.8,2.4,3.2,4.2,5.5$ and $7.5 \mathrm{~m}$ are not considered while plotting the anisotropic 


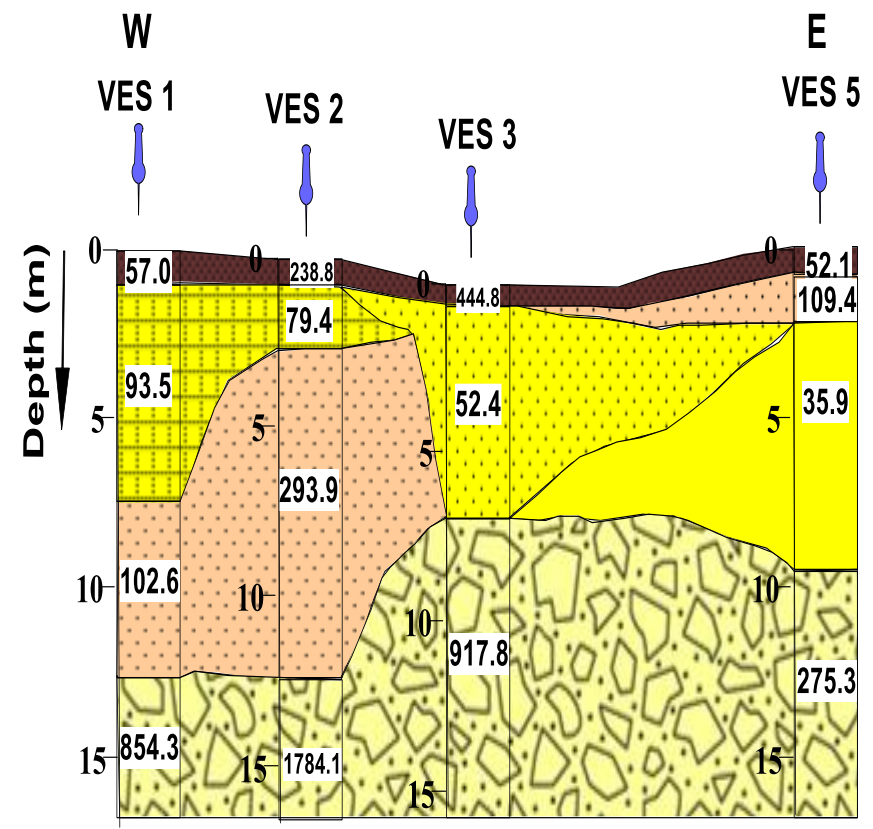

\section{LEGEND}

\begin{tabular}{|ll} 
& Topsoil (Lateritic+Sandy soil) \\
& Sandy Soil \\
\hline & Clayey Sand \\
& Sandy Clay \\
& Clayey soil \\
5.5 & Weathered/Fractured Basement \\
\hline 57.0 & Resistivity $(\Omega \mathrm{m})$ \\
\hline
\end{tabular}

Figure 2a. Geo-electric section of profile A.

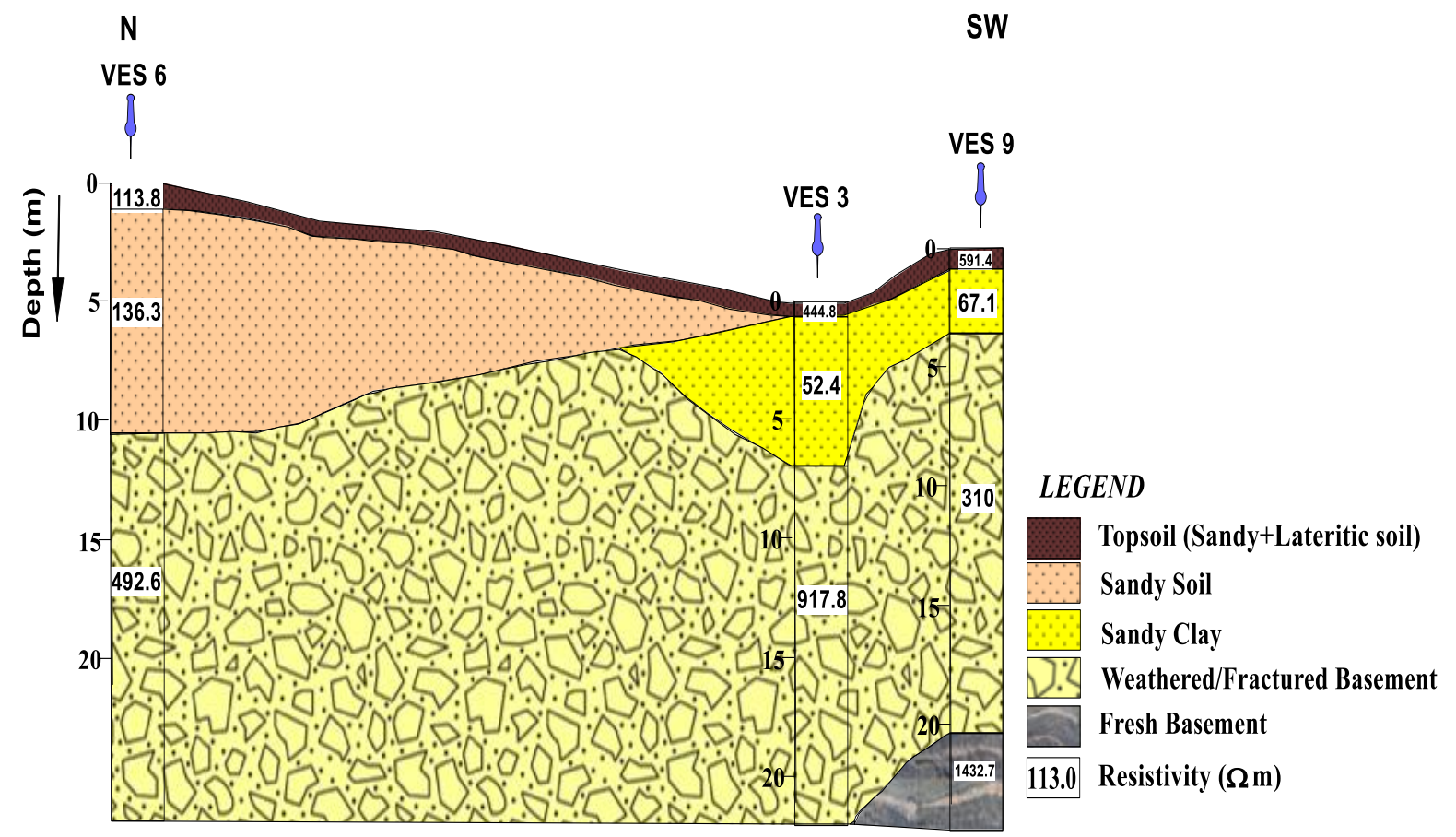

Figure 2b. Geo-electric section of profile B.

polygon.

Assuming fractures to be the major cause of anisotropy in the rock mass, the direction of the maximum apparent resistivity measured by the array will be parallel to the dominant fracture strike orientation of a collinear array (Habberjam, 1972). Discussed below are the locations 


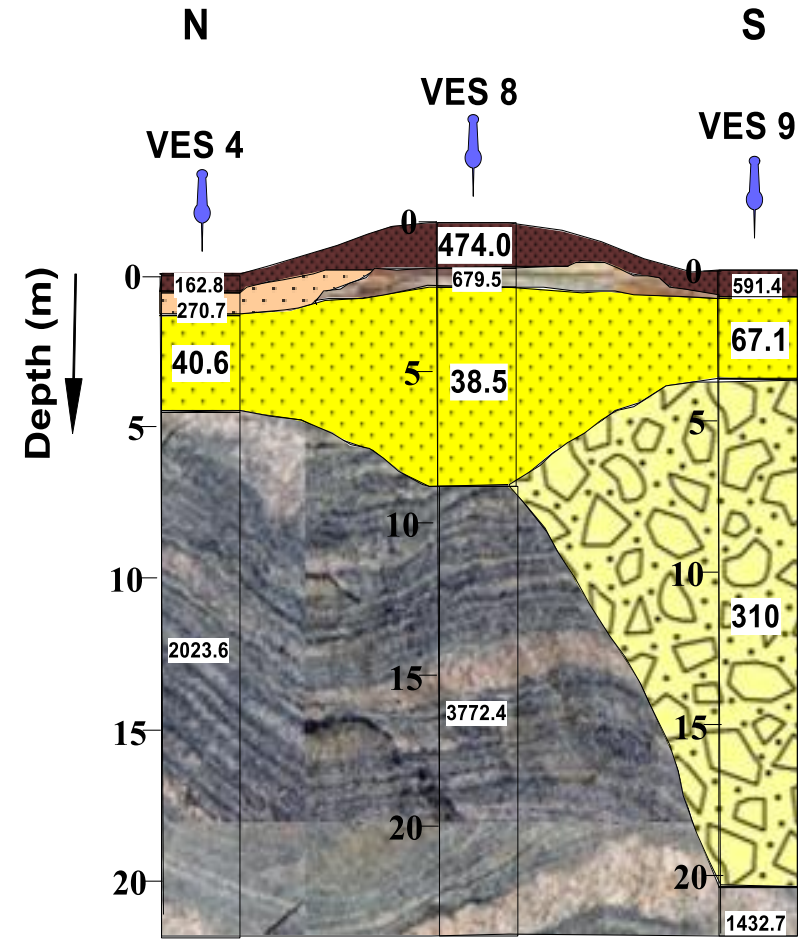

\title{
LEGEND
}

Topsoil (Sandy+Lateritic soil)

E. Compacted Laterite

$\because \quad$ Sandy Soil

$\because \quad$ Sandy Clay

U. Weathered/fractured basement

Fresh Basement

162.8 Resistivity $(\Omega \mathrm{m})$

Figure 2c. Geo-electric section of profile C.

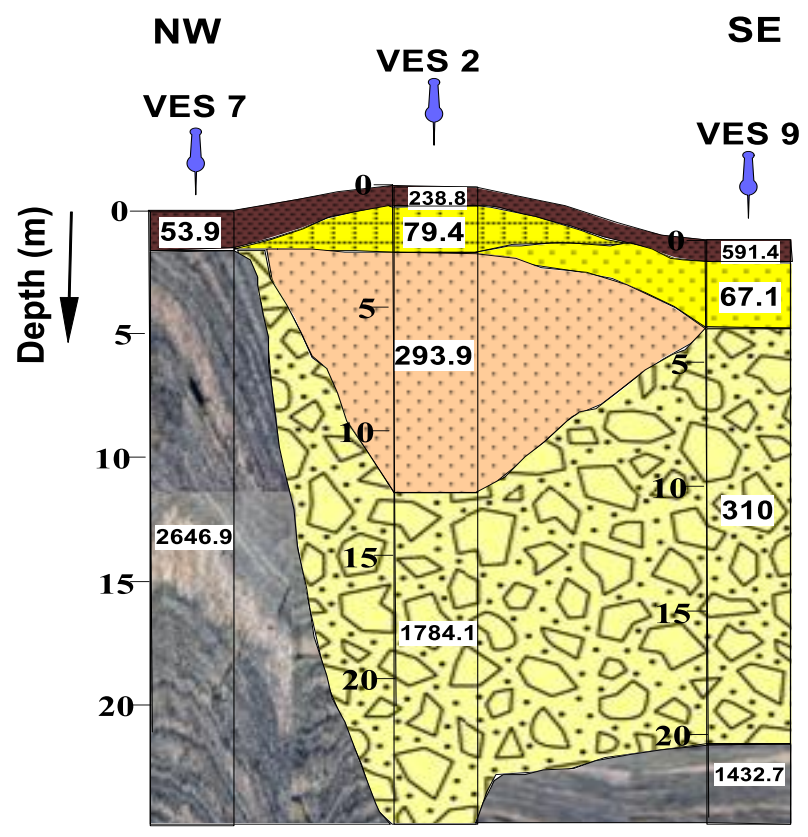

\author{
LEGEND \\ Topsoil (Sandy+Lateritic soil) \\ Clayey sand \\ Sandy Clay \\ Sandy soil \\ Weathered/Fractured Basement \\ Fresh Basement \\ 238.8 Resistivity $(\Omega \mathrm{m})$
}

Figure 2d. Geo-electric section of profile D.

where the RVES were carried out.

\section{Radial Vertical Electrical Sounding 1 (RVES 1)}

Graph of degree of fracturing against electrode spacing
(Figure 3a, Table 2) for RVES 1 indicates that fault/fractures also exists at shallow depths as well. However, foundations in this area which are generally shallow and well-seated on the fresh basement seem to have vertical and near vertical cracks as a result of 


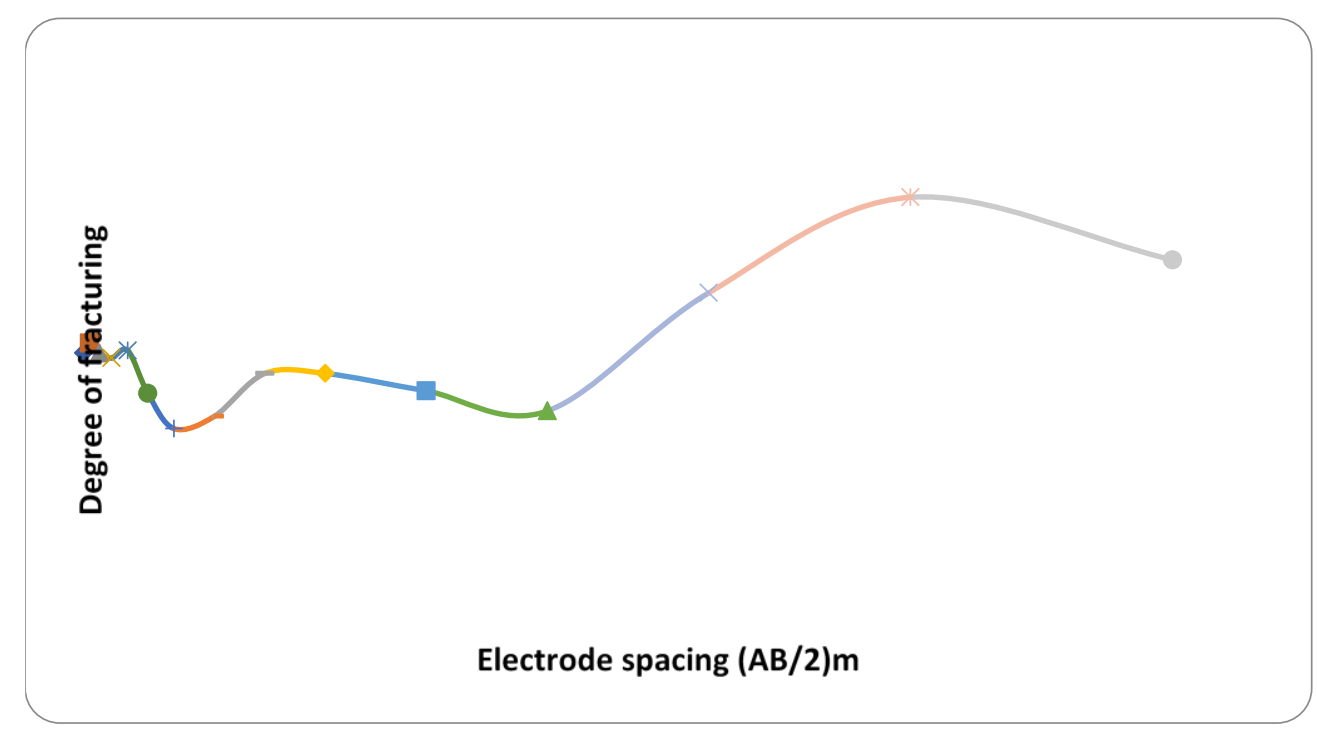

Figure 3a. Graph of degree of fracturing with electrode spacing (AB/2) m for RVES 1.

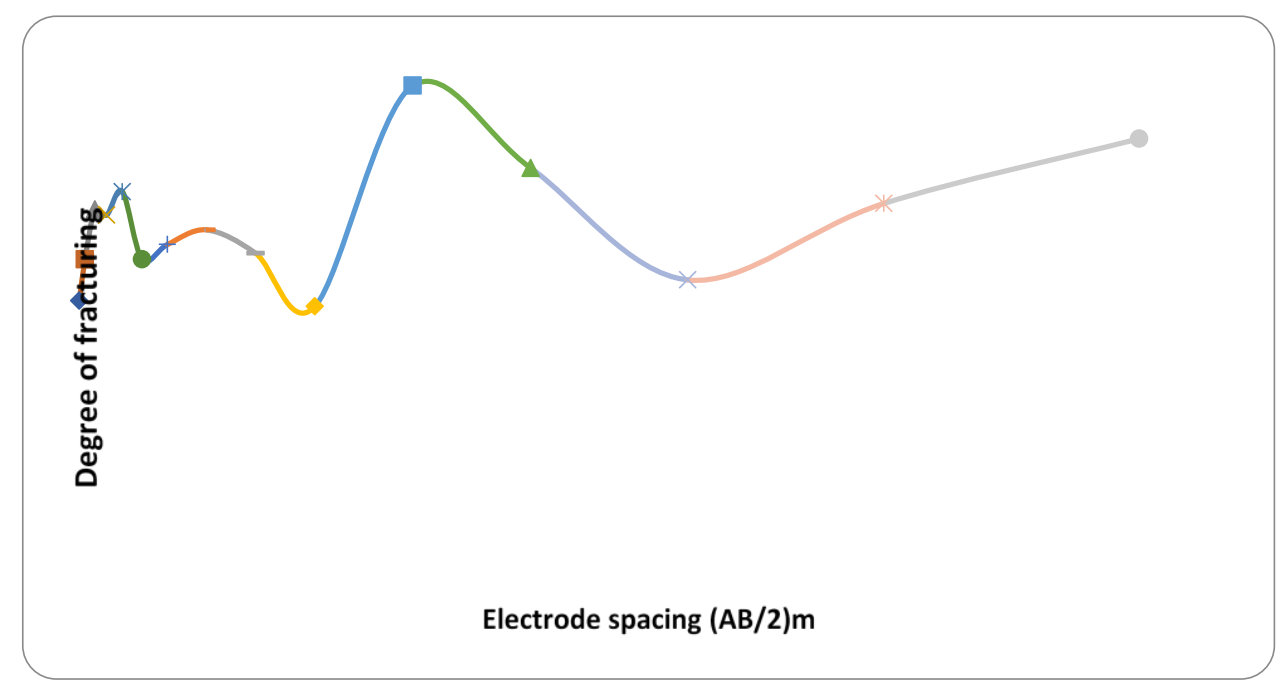

Figure 3b. Graph of degree of fracturing with electrode spacing (AB/2) m for RVES 2.

fractures within the basement created by the impact of the blasting activities. The shallow depth fractures will be liable to transmit the waves to nearby buildings.

\section{Radial vertical electrical sounding 2 (RVES 2)}

Graph of degree of fracturing against electrode spacing (Figure 3b, Table 2) for RVES 2 indicates that fault/fractures exists at shallow depths as well. Less impact was observed in this area. This might be due to the fact that most foundations are usually on the second layer and they are far away from the blasting activity. In this case, the second layer is a compacted laterite and is known to be a good natural foundation material (Omotoso et al., 2012). It may assist in protecting the foundation coupled with the use of competent building materials.

\section{Radial vertical electrical sounding 3 (RVES 3)}

Generally, buildings found within this area have shallow foundation of between one to two meters. The thickness of the first and second layers implies that buildings around here will have their foundations founded on sandy clay which can still support foundation. The buildings around here feel less impact of the blasting activity; this might be as a result of fracturing no t well pronounced like is seen 


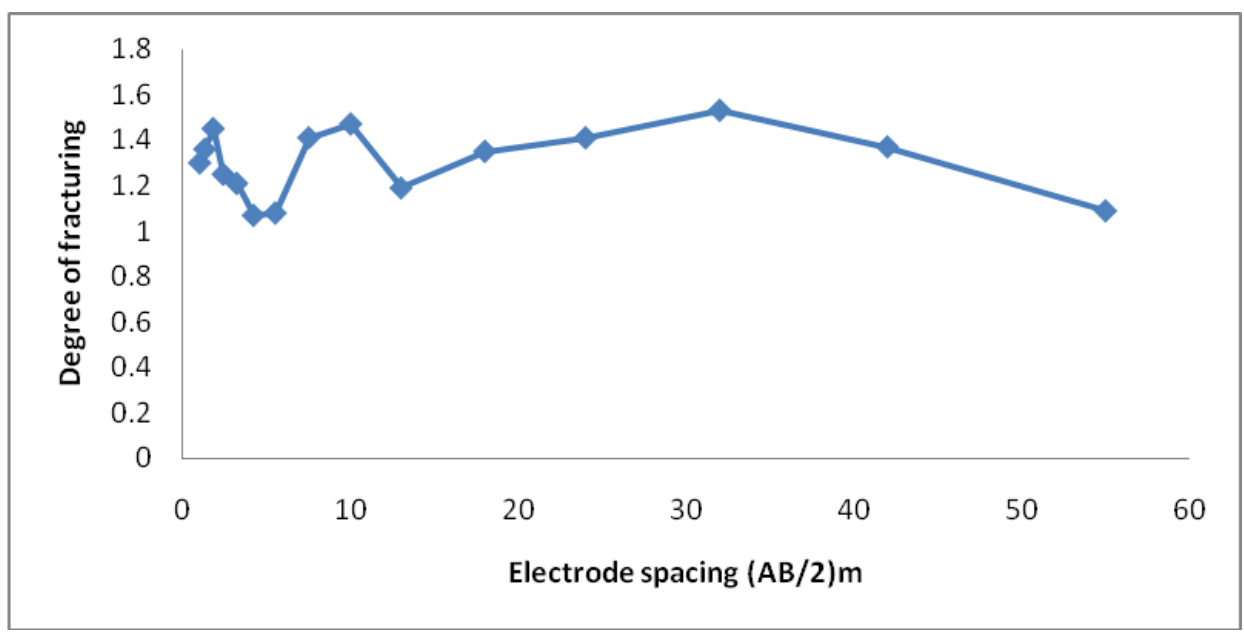

Figure 3c. Graph of degree of fracturing with electrode spacing (AB/2) m RVES 3.

Table 2. Degree of fracturing (Coefficient of anisotropy) for RVES.

\begin{tabular}{lccc}
\hline $\mathbf{A B} / \mathbf{2}(\mathbf{m})$ & RVES 1 $\left(\boldsymbol{\lambda}_{\mathbf{~}}\right)$ & RVES 2 $\left(\boldsymbol{\lambda}_{\mathbf{2}}\right)$ & RVES 3 $\left(\boldsymbol{\lambda}_{3}\right)$ \\
\hline 1.0 & 1.32 & 1.16 & 1.30 \\
1.3 & 1.36 & 1.30 & 1.36 \\
1.8 & 1.32 & 1.47 & 1.45 \\
2.4 & 1.30 & 1.45 & 1.25 \\
3.2 & 1.33 & 1.53 & 1.21 \\
4.2 & 1.16 & 1.30 & 1.07 \\
5.5 & 1.02 & 1.35 & 1.08 \\
7.5 & 1.07 & 1.40 & 1.41 \\
10.0 & 1.24 & 1.32 & 1.47 \\
13.0 & 1.24 & 1.14 & 1.19 \\
18.0 & 1.17 & 1.89 & 1.35 \\
24.0 & 1.09 & 1.61 & 1.41 \\
32.0 & 1.56 & 1.23 & 1.53 \\
42.0 & 1.94 & 1.49 & 1.37 \\
55.0 & 1.69 & 1.71 & 1.09 \\
\hline
\end{tabular}

within RVES 1 and RVES 2 regions. Graph of degree of fracturing against electrode spacing (Figure 3c, Table 2) for RVES 3 indicates that fault/fractures also exists at shallow depths but dies out with greater depth. The values of the degree of fracturing was found not to exceed 1.53 in this region which was not the case with the previous radial vertical electrical soundings, 1.94 was calculated as the highest degree of fracturing for RVES 1 while 1.83 was calculated for RVES 2. In all the RVES, degree of fracturing ranges between 1.02 to 1.94 .

\section{Conclusion}

The use of geophysical methods becomes imperative in order to establish the main cause of these damages. Electrical resistivity methods were used to delineate the make-up of the sub-surface. The geo-electric section established in Figures 2a-d along W-E, W-SW, N-S and NW-SE profiles delineated the Geo-electric layers on which foundations can be laid on. These layers are the topsoil/lateritic soil, sandy clay/clayey sand and sandy soils. All these layers while considering their geo-electric parameters (resistivity and thickness) have the strength to hold foundations.

The existence of fault/fractures in the bedrock has been confirmed by the results of the RVES which showed the presence of a multi-fracturing system. Shallower fractures are liable to transmit the waves generated during the quarry blast to nearby buildings, as the depth of the blast increases at the quarry site, the deeper fractures will serve as a conduit in transmitting the energy being generated.

Conclusively, the result of this research work has confirmed that the structural damage on buildings within 
the vicinity of the Ratcon Quarry is as a result of negligence on the part of the quarry operators by not conforming with the rules and regulations stipulated by the United States Bureau of Mines which stated that the peak particle velocity should not exceed $50.8 \mathrm{~mm} / \mathrm{s}$. This was exceeded by the Ratcon Quarry (Adetoyinbo et al, 2010).

\section{Recommendation}

Casting would have been a very good alternative for residents in this area provided it is reinforced with good materials using appropriate proportions. However, from the outcome of the investigation, the following recommendations are suggested to prevent further failures:

1. Erection of structures within $1500 \mathrm{~m}$ is supposed to be prohibited. Quarries should be made to adhere strictly to United Nation Bureau of mines recommendation PPV of $50.8 \mathrm{~mm} / \mathrm{s}$. Any quarry contravening it should be seriously sanctioned and has its license revoked.

2. Raft foundations are advised for structures around quarrying or mining areas.

\section{CONFLICT OF INTEREST}

The author declares that there is no conflict of interest.

\section{REFERENCES}

Adelusi, A. O., Akinlalu, A. A., \& Nwachukwu, A. I. (2013). Integrated geophysical investigation for post-construction studies of buildings around School of Science area, Federal University of Technology, Akure, Southwestern, Nigeria. International Journal of Physical Sciences, 8(15), 657-669.

Adetoyinbo, A. A., Popoola, O. I., Hammed, O. S., \& Bello, A. K (2010). An Assessment of quarry-blasting vibration impacts in Ibadan and Abeokuta, Nigeria. European Journal of Scientific Research, 44(2), 228-252.

Bhattacharya, B. B., \& Patra, H. P. (1968). Direct Methods in Geo-Electric Sounding: Principle and Interpretation. Elsevier Science Publication Company. Inc. p. 131.
Felice, J. J. (1993). Application of modeling to reduce vibration and air blast levels. Paper presented at the 4th International Symposium on Rock Fragmentation by Blasting, Viennaa, 5-8 July, 1993.

Habberjam, G. M. (1972). The effects of anisotropy on square array resistivity measurements. Geophysical Prospecting, 20(2), 249-266.

Johnson, G. J., \& Durucan, S. (1994). The numerical prediction, analysis and modeling of ground vibration induced by blasting. Paper presented at 3rd international symposium on Mine Planning and Equipment Selction, Istanbul, 18-20 October, 1994.

Okunlola, O. A., Adeigbe, O. C., \& Oluwatoke, O. O. (2009). Compositional and petrogenetic features of schistose rocks of Ibadan Area, southwestern Nigeria. Earth Sciences Research Journal, 13(2), 119-133.

Olayinka, A. I. (1996). Non uniqueness in the interpretation of bedrock resistivity from sounding curves and its hydrological implications. Water Resources Journal of NAH, 7(1\&2), 55-60.

Omosanya, K. O., \& Ajibade, O. M. (2011). Environmental impact of quarrying on Otere village, odeda, Southwestern Nigeria. Ozean Journal of Applied Sciences, 4(1), 75-82.

Omotoso, O. A., Ojo, O. J., \& Adetolaju, E. T. (2012). Engineering properties of lateritic soils around Dall quarry in Sango Area, Ilorin, Nigeria. Earth Science Research, 1(2), 71-81.

Paolucci, R. (1997). Simplified evaluation of earthquake-induced permanent displacements of shallow foundations. Journal of Earthquake Engineering, 1(03), 563-579.

Richard, F. E., Hall, J. R., \& Woods, R. D. (1970). Vibrations of Soil and Foundations. The National Academies of Sciences, Engineering, and Medicine. 500 Fifth Street, NW | Washington, DC 20001.

Singh, B., \& Roy, P. P. (1993). Blasting in Ground Excavation and Mines. Balkema, Rotterdam Publisher, ISBN: 9061919568.

Uysal, O., Elvi, B., \& Akcakoca, H. (2004). Environmentally sensitive drilling and blasting design for a surface mining. 13th International Symposium on Mine Planning and Equipment Selection, 1-3 September, Wroclaw, Poland.

Venkatesh, H. S. (2005). Influence of total charge in a blast on the intensity of ground vibrations-field experiment and computer simulation. Fragblast, 9(3), 127-138. 